\title{
'The Dream of the Unified Field': Originality, Influence, the Idea of a National Literature and Contemporary American Poetry
}

\section{Ruediger Heinze}

\author{
(2) OpenEdition \\ Journals \\ Electronic version \\ URL: https://journals.openedition.org/ejas/2482 \\ DOI: $10.4000 /$ ejas. 2482 \\ ISSN: 1991-9336 \\ Publisher \\ European Association for American Studies
}

Electronic reference

Ruediger Heinze, "'The Dream of the Unified Field': Originality, Influence, the Idea of a National Literature and Contemporary American Poetry", European journal of American studies [Online], 3-3 2008, document 2, Online since 20 August 2008, connection on 08 July 2021. URL: http:// journals.openedition.org/ejas/2482 ; DOl: https://doi.org/10.4000/ejas.2482

This text was automatically generated on 8 July 2021.

Creative Commons License 


\title{
'The Dream of the Unified Field': Originality, Influence, the Idea of a National Literature and Contemporary American Poetry
}

\author{
Ruediger Heinze
}

\section{Paradigm Lost}

1 On the back cover of the 1994 Norton anthology Postmodern American Poetry, a commentary claims that the collection is the first to "fully represent the movements of American avant-garde poetry." Beginning with a poem by Charles Olson from 1953, it contains 411 poems by 103 different poets, from the Beats, the New York School and the Projectivists to a general "array of poetry written since 1975." The selection ranges from John Cage, Charles Bukowski and Jack Kerouac to Denise Levertov, Robert Creeley and Amiri Baraka to Jerome Rothenberg, Susan Howe, Bruce Andrews and Lyn Hejinian. The last entries are from 1992, thus the volume covers a time span of just short of forty years. Apart from the fact that this anthology is not the only one to lay claim to a representative selection of "avant-garde" American poetry - conflating with a sleight of hand "avant-garde" and "postmodern" - the range and variety of the selection in effect empties the title term "postmodern" of all definitive quality. The exclusion of some poets, such as Robert Lowell or Sylvia Plath, for the inclusion of others, such as Bruce Andrews or Charles Bernstein, affords no marked difference to other similarly wide-ranging anthologies of contemporary American poetry, as long as "contemporary" is taken to cover the period after WWII. As a matter of fact, it appears that for this particular anthology the substitution of the term "postmodern" for a rather bland "contemporary" would not amount to a qualitative difference of any import, except for the fact that the same publisher also offers an anthology of modern and contemporary American poetry. ${ }^{2}$

2 Although the editors, Hoover and Chernoff, introduce the collection by arguing that they do not view postmodernism as a single style but rather as "an ongoing process of 
resistance to mainstream ideology" (Hoover xxvi), this merely relegates the problem to another, similarly illusive, arena; apart from the fact that the logical consequence of such argument would be that Ginsberg, who by now has become an icon of American poetry and very much mainstream, is somehow more subversive than, for example, Robert Lowell. The collection is thus an attempt and simultaneously testimony to the failure of such an attempt to come to terms with contemporary American poetry by arguing for a literary historical genealogy arranged around the opposition of mainstream and subversiveness. This in turn is implicitly based on the idea of the aesthetic and significantly moral inadequacy of mainstream poetry, versus the authenticity and truly poetic success of subversive poetry. Needless to say, such authenticity commonly is the defining characteristic of a genuinely American poetic tradition that, according to such argument, almost inevitably goes back to Whitman and Dickinson.

3 A similar, more recent argument is made in Alan Kaufman's introduction to the 1999 Outlaw Bible of American Poetry:

Here are the [...] poets who don't get taught in American poetry 101, yet hold the literary future in their tattooed hands. [...] The Academy had best make room for these descendents of Whitman's 'Roughs' and Emerson's 'Berserkers': Our poets can whip your poets' asses. (Kaufman xxv)

Not surprisingly, the collection is not as wild as it heralds to be. Whitman, Williams, Ginsberg, Reed and other fairly "101" poets have made it into the collection alongside a number of well-known "outlaws" (Patti Smith, Tom Waits, Jackson Pollock, Kathy Acker), genre benders (Diane diPrima, Richard Brautigan, David Lerner), and native American and "ethnic" poets (Joy Harjo, Simon Ortiz, Luis Rodriguez, Victor Hernández Cruz). What is perhaps the most remarkably "outlaw" feature of the collection is the variety of texts that are gathered under the auspices of "poetry." The "tattooed hands" that "whip asses" here only give a less academic expression to the "resistance to mainstream ideology"-sentiment found in the Norton anthology.

What is at stake here is not an intervention in the already overly strained debate over the use of "postmodern" and "subversion vs. mainstream" for discussing contemporary American poetry, but closer attention to the underlying rhetoric that suffuses critical discussions around the aesthetics, poetics and cultural and material conditions of American poetry. Under the precept of originality, poets and critics call for and on occasion celebrate a specifically American, coherent national poetry. ${ }^{3}$ Conversely, others bemoan the "forfeiture of grand opportunities" exactly because contemporary American poetry fails to contribute to a genuinely innovative national literature due to the "academization" and "inbred professionalism" of the creative writing programs (Altieri, Self 205). I would argue that these two lines of argument are only in apparent opposition to each other: both are based on similar notions and specifically American traditions of a poetics of influence from Ralph Waldo Emerson, T.S. Eliot to Harold Bloom. As this essay will further argue, these two arguments usually appear in the context of discussions around the idea and ideal of a national literature.

2. Forfeiture vs. Coherence

No poet since Whitman has tapped into so many distinctly American voices and, at the same time, so preserved his utterance against the jangle of influences (Schultz on John Ashbery 1).

Looking back on the preceding decade, the poet Robert Shaw asserts that "the drink of the 1890s was absinthe; that of midcentury was gin; that of the 1990s appears to be 
Cranapple Juice" (Shaw 217), possibly wholesome but definitely not stimulating. He finds a "reflexive caution" among contemporary poets, a "forfeit of grand opportunities" (Shaw 219). This is, he claims, largely due to the fact that a whole generation of poets has been raised in the incestuous system of the creative writing programs at universities, where students are streamlined in the process of being taught the mechanics of writing poetry and the imperative to avoid risks. Creativity, so the criticism, is presumptuously assumed to be teachable, while at the same time the future poets are deprived of the chance to wean themselves off the influence of their tutors in order to establish their own individual voices and, following Pound's notorious dictum, "make it new." According to this argument, it is hardly surprising that such a system should fail to produce great American poets. ${ }^{4}$

7 Indeed, there has been an increasing institutionalization of poetry in the MFA programs (gradschool.com lists 161 MFA graduate degree programs in the US) and writers' conferences. A substantial number of writers actually earn their living by writing and teaching, a situation which, considering its uniqueness in comparison to other countries, should not be underemphasized since it furthers the proliferation of professional writers. This itself is reason enough for many attacks because the notion of writing as a profession in which money can be earned (even if little) does of course leave hardly any space for a notion - or self-projection - of writing romantically connoted with creativity, genius and societal marginality. ${ }^{5}$ The self-sustaining nature of this institutionalized system has naturally come under attack especially from those outside it. Critical essays on American poetry are saturated with disdainful remarks about academic (or "commodity") poets on the grounds that writing for money compromises the quality of the work, aesthetically and politically. They are, paradoxically, criticized for their "homogenizing tendencies, [...] for producing too much poetry too quickly and for emphasizing quantity at the expense of quality" (Beach 37) exactly in the name of a qualitative, implicitly homogeneous national poetry that needs to be salvaged and defended against these epigones. ${ }^{6}$ While few critics care to specify their notion of the 'academic poet,' there doubtlessly are possible detrimental effects to university programs that are maintained by recruitment from their own system. However, evidence to the contrary is tendentiously ignored: many of the poets most widely recognized as productive and innovative, such as John Ashbery, Louise Glück, Jorie Graham and Adrienne Rich, are also at least to some extent products of and/or participants in that system and have - in the words of Adrienne Rich profited from not having to worry about how "to put bread on the table" (40). It is not so much the fact of the existence of the writing programs themselves that should be critiqued - nor necessarily their institutional affiliation or monetary interests - but the underlying double bind: yes, one can learn how to write poetry, there is something like a common base that students can potentially acquire and contribute to, a base that is also the ground for the "maturation" of a national poetry; but on the other hand there is the imperative to be original, uninfluenced. In effect, this implies that to write American poetry means to be original, an equation which echoes Pound's imperative to "make it new."

8 Apparently, the celebration of a coherent and unified national American poetry with a clear lineage would seem to run counter to this argument. In 1999, the Poetry Society of America invited poets to a panel discussion on what is American about American poetry. The poets' responses can still be found on the society's internet site 
(www.poetrysociety.org/whatsamer.html). While no single definition or short list of criteria can be abstracted from the responses, the topic itself indicates interest in poetry as a - specifically national - cultural database and a function of cultural archive and memory: Catherine Bowman (poetry correspondent of the NPR show All Things Considered) finds that current poetry is based on the rhythms of American speech and on a reinforced oral tradition (Bowman $\mathrm{xv}$ ) proliferating in open-mic readings frequently held in bars, poetry slams, and other public venues. ${ }^{7}$ This would contradict the view that poetry is the "most private and least public of traditional literary genres" (Göske 229). Edward Hirsch writes (1ff) that the great invitation of American poetry, namely Whitman's, is still true:

Stranger, if you passing meet me and desire to speak to me, why should you not speak to me? / And why should I not speak to you? (Whitman 14)

According to this view American poetry can "contain contradictions and multitudes" and poets should "resist much, obey little." Campbell McGrath states in an interview that the "poems my students write in Spanish or Jamaican patois still feel like American poems to me - it's in the cadence, the energy, the cultural database, the concerns of immigration, acculturation, Americanization" (http://www.pitt.edu/ $\sim$ nidus/archives/fall2002/mcgrath.html). The well-known problem is that the idea of a national identity achieved through literature (poetry) is a foreshortening of the multitude of different voices in American poetry (Göske 229ff) if that multitude is not taken as a defining feature of that national poetry, which in turn makes delineation extraordinarily difficult. The reference to an American poetry and a distinctly American national literature and tradition is not ontological but mostly ideological in the Althusserian sense and part of political discourses, though not always, as Benedict Anderson points out in a recent interview, to negative effect. It may indeed serve a utopian function of projecting a Good Nation in the abstract (www.culcom.uio.no/ aktivitet/anderson-kapittel-eng.html). Nevertheless, in practice, "[t]he eagerness to construct 'national' genealogies produces questionable results" (Göske 230) because differences are inevitably subsumed under the mission of projecting the idea of a national literature with a common national lineage, although it should be granted that considering the notion of "Americanness" is not per se unproductive as long as that notion is acknowledged as ideological and complemented by a larger context of historical, political and international influences (231). However, as Göske points out, this manner of selection will always run the danger of losing sight of transnational aspects, translation, immigration, etc.

3. The Influential Fallacy

A great man quotes bravely. (Emerson, Letters 183)

[N]ot imitation, but creation is the aim. (Emerson, Works, Vol II 209)

If contemporary poets forfeit grand opportunities and fail to write "great American poetry" because the writing programs obstruct their finding of an individual voice, the assumption is that creativity and originality can only be had through a struggle against the influence not only of one's tutor but of the entire tradition of American poetry. Yet to allow for later incorporation into an American tradition, poetry at some point needs to be recognized as distinctly American. This is what John Ashbery is lauded for in the above quote from the introduction of a collection of essays entitled The Tribe of John: being American yet being distinct, maintaining one's discernible voice among the many voices of American poetry. The romantic myth of the independent, individualistic and potentially solipsistic genius who finds his or her authentic voice in a struggle to 
simultaneously repudiate, acknowledge and somehow master a great tradition is at the core of such rhetoric. As David Herd neatly points out in his study on Ashbery, the latter is ideal for such appropriation because he is regarded by a host of critics as both mainstream and avant-garde (Herd 1) and can consequently be enlisted for a variety of critical projects. Accordingly, contemporary American poetry is a continuous falling away from the image of perfection of the great, self-reliant American artists and their artistic tradition. Likewise, celebrating a distinctly American national poetry or even just holding up the idea as an ideal evokes the notion of a long lineage of great American poets who have through consecutive influence on their respective "progeny" built and contributed towards this national literature. In the extreme, this would imply that all contemporary poetry (or at least the "good") could basically be traced back to a few model figures, say Stevens, Williams, Whitman and Dickinson. Indeed, over the course of time a substantial number of literary critics have argued exactly that, especially in the early formative period of American studies. Carl Bode introduces his collection of essays by other critics, Great Experiment in American Literature (1961), by arguing that "[o]ne of the signs of the American character is an interest in trying something new" (Bode vii), a unique experimentalism that discards with tradition to find new ways. Bernard Duffey's Poetry in America (1978) proclaims the Age of Bryant, Whitman and Pound respectively, while Mutlu Konuk Blasing's American Poetry (1987), identifies four distinct lines from Emerson, Poe, Whitman and Dickinson. The most recent example of this kind of artistic genealogy is contributed by Angus Fletcher's New Theory for American Poetry (2004), which once again takes Whitman as its starting point.

11 The problem is not that there is no influence but rather that there is too much, or in other words: there cannot not be influence, at least as long as one uses language and lives on this planet; as an inverse consequence, influence cannot be disproved. This is so basic an assumption as to seem facetious, but only its continued disregard can explain the fact that "influence" is rarely specified but frequently taken to account for too much and thus excluding too much (usually in the service of some particular interest), and -which is more than ironic - used without consideration for its history and tradition. For example, the collection The Tribe of John has gathered various essays which are supposed to testify to the influence of John Ashbery on contemporary poetry (the title suggests a tribal following) and provide examples of the kind of influences. ${ }^{8}$ According to this collection, influence can manifest itself concretely in similar topics, syntax, imagery, length of lines and formal arrangement, and more abstractly in a rejection of closure, a play with absences and the repudiation of a coherent lyrical voice. Influence here means resemblance, variation, analogy etc. on the level of one poem, an entire collection or even an entire "period" in the poet's production. The collected essays almost without exception provide insightful and expert readings of Ashbery's poetry, but also patently demonstrate the vagueness of the term: influence is attested in so many different ways as to empty the term of almost all meaning. In effect, if a contemporary poet lays claim to or denies having been influenced by Ashbery, there is little definitive ground for disproving or endorsing the claim, whichever it is. Even if we do not credit the poet's statement, influence could come about by rejection and/or inversion, it could be non-intentional or disjunctive. To put it bluntly: while influence exists in multifold abundance, it would appear to be almost impossible to systematize, quantify, or qualify. Chance, however, is not a methodologically appealing category. Why, then, the continuing reference - implicit or explicit - to influence? As I argued above, both the idea of forfeiture and the idea of 
coherence, respectively national poetry, more or less implicitly resort to and rely on a shared assumption of influence. This assumption deserves more scrutiny.

Harold Bloom's is perhaps one of the best-known and influential (pun intended) contemporary comment on influence. He argues that every strong poem is a misreading of those that precede it so that poets can "clear imaginative space for themselves" (Bloom 5). Influence here mostly manifests itself in intertextuality. Strong creative will and individuality are of utmost importance and manifest themselves in an original and innovative (mis-)reading of the model. The strong poet is thus an anxietyridden adulator and iconoclast. This manner of intertextual reference and reverence is reminiscent of what T. S. Eliot demanded for strong poetry in "Tradition and the Individual Talent." According to him, "no poet, no artist of any art, has his complete meaning alone. His significance, his appreciation is the appreciation of his relation to the dead poets and artists" (Eliot 4). At the same time, the individual talent with each new creation alters what precedes it, rewriting the tradition, an idea that resonates with Borges contestation that every writer creates his or her own precursor.

Both Bloom and Eliot stand in the tradition of Emerson, and occasionally their texts even read like a paraphrase of the master:

All minds quote. old and new make the warp and woof of every moment. There is no thread that is not a twist of these two strands. By necessity, by proclivity, and by delight, we all quote. We quote not only books and proverbs, but arts, sciences, religion, customs, and laws; nay, we quote temples and houses, tables and chairs by imitation. (Emerson, Letters 178)

Similarly to Eliot and Bloom, Emerson elaborates on the paradox of borrowing and inventing, emulating and misreading, tradition and originality: "Only an inventor knows how to borrow, and every man is or should be an inventor" (Emerson, Letters 204). In this tradition, the poet is a strong-willed individual whose creative genius allows him or her to write with and against an overwhelming tradition, altering it and thus leaving an imprint of their originality on the genealogy of great American literature.

These notions have not gone uncontested: if intertextual reference, whether by allusion, paraphrase, or parody, is taken to be inevitably a form of misreading because of its re-location in a new context, as Derrida claims in his dispute with Searle, then Bloom's argument holds true because all such references are then misreadings, but is also deprived of its argumentative strength because strong creative will and intention lose their relevance. ${ }^{9}$ Moreover, it would be inordinately difficult to delimit the intertextual play found in contemporary poetry by seeking effects of anxiety or the strain to establish a new tradition, a poetic voice free of and different from its predecessors, possibly because of the recognition that such attempts stand in the tradition of a romantic author-concept disparaged by Foucault and Barthes. ${ }^{10}$ Nevertheless, exactly this notion of influence is at the core both of claims that academy workshops cannot produce good poetry, where good poetry stands in the tradition of contra-mainstream and thus typically American poetry (a tradition of the exceptional, so to speak), and that there is a recognizable, coherent national lineage of great American poetry continued to today. ${ }^{11}$ As contested as the idea may be, without it both lines of reasoning would collapse and with it two convenient and highly politicized discourses on a national literature. 

poetry that fits these ideas, a criticism which, indeed, has its own longstanding, one might ironically say: specifically American literary tradition. As MacGowan points out, for "many nineteenth-century English writers and critics [...] American literature, if such a thing existed, was merely a provincial offshoot of English literature" (McGowan 276). Against this bias, laying claim to an American original identity and independence, of nation and literature, was an obvious counter, most emphatically pronounced by Hector St. John de Crevecoeur, Alexander de Tocqueville, Ralph Waldo Emerson and Walt Whitman. Subsequently, at the beginning of the $20^{\text {th }}$ century, with the rise of the university and its literature departments, the call for/claim of the necessity, and simultaneous decrying of the absence of a national American literature continued a century old debate, a debate, indeed, that in its structure is common to all struggles about a national literature and thus not specifically American. The critic Van Wyck Brooks chimes in with the lament of not having strong writers (191) in his last of Three Essays on America (1934), a lament that Howard Mumford Jones takes up in a chapter entitled "A National Spirit in Letters" (48-78) in his Theory of American Literature (1948). Complementing these complaints are attempts at defining just what is originally American about American literature and poetry, continuing to today: its quintessential modernity (Auden), its portrayal of "how Americans live in America" (van Doren 2), the persistence of the theme of the dignity of man (Pearce), the continuing centrality of Emerson (Waggoner), or, more contemporary, the dialectic between a formal sensibility and social responsibility (Altieri).

Common to most of these literary histories are dialectic structures of opposites, in turn more often than not based on implicit ideas of forfeiture and coherence, originality and influence. As pointed out above, these lines of reasoning can be illuminating, but also restrictive. Just what kind of faultlines are left out can be seen in the thematically organized table of contents of Stephen Fredman's Concise Companion to Twentieth-Century American Poetry (2005): feminism, queerness, immigration, mysticism, war, transnationalism, science, philosophy, etc. One way to avoid the influence of these dialectic literary histories of originality and influence is to seriously acknowledge the multiplicity of contemporary American poetry, not just to give it "a nod of recognition," then to be "simply absorbed into the more or less same-as-usual American canon," as Robert Lee describes a typical gesture for ethnic texts (Lee 5).

4. Once More: The Multiplicity of Contemporary American Poetry

One defining characteristic of American poetry is its diversity, its inability to be pigeonholed or represented by one or two major figures and models. There is no binding consensus on what is essential in our poetry right now. This superabundant complexity may seem maddening to those whose business it is to impose rational categorization upon disorder - namely critics and theorists - but to poets it ought to feel like an entirely welcome and delightful state of affairs. (http:// www.poetrysociety.org/mcgrath.html)

In an essay on American poetry of the 1990s, Willard Spiegelman starts with a literary parlor game, making two separate lists of poets and asking what sets them apart (Spiegelman 206). There appears to be no distinguishing criterion, but there is: one group won the Pulitzer Prize for Poetry in the last decade, the other did not. The list of Pulitzer poets - the Pulitzer Prize is surely one powerful mechanism of marketing and canonization - indicates that even such a fairly popular award honors an increasingly

European journal of American studies, 3-3 | 2008 
diverse and multicultural American poetry. Even more radically experimental, on-thefringe, marginal and/or ethnic poets are being canonized and institutionalized. One need not look far to find them published in the respective anthologies by, for example, Douglas Messerli, Charles Bernstein or Ron Silliman.

These anthologies as well as smaller collections with different purposes (e.g. by Finch and Varnes, Bowman and Lehman) give witness to apparently important developments in American poetry and as a corollary also to the foremost ideological nature of a national poetry, for several reasons. First, the extreme division between new-formalists and $\mathrm{l}=\mathrm{a}=\mathrm{n}=\mathrm{g}=\mathrm{u}=\mathrm{a}=\mathrm{g}=\mathrm{e}$ poets, New York School and Projectivists and countless other movements has evidently long become obsolete and increasingly useless for discussing contemporary poetry. Granted, the affiliation of a poet with a particular school and/or tradition might still be helpful in order to locate him or her within certain traditions (e.g. Ted Kooser or Charles Wright), but despite all polemical contention to the contrary (for example by Lyn Hejinian, Bruce Andrews or Robert Bly), these affiliations are dissolving. As poet David Kellogg points out, "there is no one site for resistance or authenticity" (qtd. in Finch and Varnes 2). One of the reasons for the dissolving affiliations is a shifted attitude towards formal experiment. The output of literature journals and book publishers shows that the poetry published in the US is more open to a variety of forms - formal verse, prose poems - than it used to be twenty years ago; there is a noticeable shift in attitude towards formal matrices as well as to a less polemically fraught attitude towards formal experiment per se, though so-called free verse is admittedly still the preferred "form." For the most part of the last century formal matrices were eyed suspiciously because "many poets and critics, both traditional and experimental, have suggested that to write in certain forms is incompatible with postmodern insights about the contingency and fragmentariness of the self" (Finch and Varnes 2). ${ }^{12}$ For some time now, however, there has been a prolific and occasionally playful resurgence of formal matrices, e.g. such arcane forms as the sestina or the canzone, in the poetry of a number of older and younger contemporary poets.

Second, what currently goes under the label contemporary "American" poetry has been making use of the multifarious ethnic voices and traditions in "American" literature, often by incorporating passages in languages other than English, and of a wealth of transnational imports, as Daniel Göske demonstrates for Robert Bly, Anthony Hecht and Amy Clampitt; so much so that it often - consistent with the argument of this essay - becomes difficult to say just what nationality a text may be if the author's citizenship ceases to be the sole defining feature. For the ideal of a national poetry, this raises several problems. Many ethnic poets make use (in a number of ways) of their specific cultural background and literary traditions. They are often either labeled as American poets reflecting the intrinsically varied tradition of American literature, or as poets with a hyphenated affiliation whose work derives its merit precisely from not being part of a mainstream American poetic tradition and canon. Both views are as foreshortened as they are ideologically invested, and combined they sit uneasy with the ideal of a national poetry. Ironically but consistently, the incipient comparative transethnic, trans-national criticism that would circumvent these two perspectives sits just as uneasy with that ideal. In addition, the label "ethnic" only goes so far in dealing with poetry, as every poet, to differing degrees, makes use of his or her culturally specific 
background - in fact cannot help but do so -, which may or may not coincide with the elusive idea of a national identity.

An example: Jorie Graham, surely one of the most prominent canonical, mainstream "non-ethnic" poets, is regularly placed at least partially under the influence of John Ashbery and thus as belonging to the tribe of John. On the back cover of The End of Beauty an excerpt from Helen Vendler's review in The New Yorker announces Graham's status by invoking Blake, Whitman, Stevens, Eliot and Ashbery, names which sooner or later show up in most of her reception. It would of course be possible to enlist Graham for the project of a coherent national American literature; she makes abundant intertextual references to Whitman, Emerson, etc., has indisputable status as an influential contemporary poet with a purportedly distinct voice and an alleged lineage to key figures in American literature. It would be just as possible to question the enthusiasm with which she is commonly greeted and label her as a typical product of an "academic poetry" aesthetics geared mostly to an exclusive and intellectual audience. ${ }^{13}$ While quotations from Whitman and Emerson show her affiliations to American literature, the reference to Emerson, being the first American scholar to extensively adopt Plato into his thoughts, already alludes to further references that reach far beyond a purely American literary and cultural canon, even if most of them remain within the realms of western "high" culture (e.g. continental philosophy and literature, physics, but also less canonical texts such as Audubon's Journals or Etiquette manuals). ${ }^{14}$ Also, her manner of citation formally raises the question of what counts as a poem and what not, apart from the fact that the citations are not to be fully trusted (as she often alters sequence and layout of the original). In short: there are far too many and diverse references and influences and far too much formal complexity for Graham's poetry to be easily categorized. Her problematization of poetic form per se, her formal variations, her predominantly transnational intertextual references, all of these demand a reading beyond the two critical narratives of forfeiture of or coherence with the tradition of American poetry.

5. Conclusion

23 Jorie Graham is only one case in point. As overcome as the ideal of a national American poetry and, by extension, literature may appear, it has played (and still does play) an important political and literary historical role, even, as Anderson points out, a utopian one. It would appear that defining a national literature is more a question of identifying specific thematic preoccupations and thus a matter of content rather than formal variation. This, however, is misleading. American poetry in particular has been identified with its schools, manifestos and diverse poetics of how a poem should be. Rootedness in place and time is necessarily of importance. But the majority of poets have been characterized by their use of form, style and formal aesthetics rather than thematic focus. Scrutinizing the extant formal variety of contemporary poetry thus constitutes a viable way of widening the impression of what is "going on" in American poetry. The predominance of the two narratives of forfeiture and coherence and their foundation on a notion of influence must hence be seen as a political (more so than aesthetic) attempt to exclude post- and trans-national trends in poetry and criticism, as well as anything else that does not fit the picture, from the projection of a national American poetry. If both of these narratives inherently testify to the continuing import of influence, in whatever form, and thus implicitly to the valid and legitimate need for negotiating issues of cultural identity and memory, then the notion of influence and the concomitant negotiation of cultural identity should be revised so as to do justice to 
the fact that 1) influence is never just national and individual but transnational, multifold and complex, 2) there is no necessarily logical and systematic connection between the existence of writing programs and the quality of contemporary (American) poetry, 3) there is an abundant variety of poetry and poetic forms in contemporary (American) literature, and 4) the idea and ideal of a national literature is, for what it is worth, surprisingly resilient and, perhaps, more an ideological construction than many of us may still want to admit.

Works Cited

Altieri, Charles. The Art of Twentieth-Century American Poetry. New York: Blackwell, 2006.

- - -. Self and Sensibility in Contemporary American Poetry. Cambridge: Cambridge UP, 1984.

Anderson, Benedict. "Interview with Benedict Anderson: 'I like nationalism's utopian elements." CULCOM: Cultural Complexity in the New Norway. >http://

www.culcom.uio.no/aktivitet/anderson-kapittel-eng.html> (13 November 2006).

Andrews, Bruce. "The Poetics of $\mathrm{L}=\mathrm{A}=\mathrm{N}=\mathrm{G}=\mathrm{U}=\mathrm{A}=\mathrm{G}=\mathrm{E}$." Textual Operations Talk Series. White Box, New York City. Sept. 25, 2001.

Andrews, Bruce, and Charles Bernstein, eds. The $\mathrm{L}=\mathrm{A}=\mathrm{N}=\mathrm{G}=\mathrm{U}=\mathrm{A}=\mathrm{G}=\mathrm{E}$ Book. Carbondale and Edwardsville: Southern Illinois UP, 1984.

Beach, Christopher. Poetic Culture. Evanston: North Western UP, 1999.

Blasing, Mutlu Konuk. American Poetry. New Haven: Yale UP, 1987.

Bloom, Harold. The Anxiety of Influence. $2^{\text {nd }}$ ed. Oxford and New York: Oxford UP, 1997. Bode, Carl, ed. The Great Experiment in American Literature. London: Heinemann, 1961.

Bowman, Catherine, ed. Word Of Mouth. New York: Vintage, 2003.

Brooks, Van Wyck. Three Essays on America. New York: Dutton, 1934.

Casanova, Pascale. The World Republic of Letters. Transl. M.B. DeBevoise. Cambrigde:

Harvard UP, 2005.

Derrida, Jacques. Limited Inc. Evanston: Northwestern University Press, 1988.

Duffey, Bernard. Poetry in America, Durham: Duke UP, 1978.

Eliot, T. S. Selected Essays. London: Faber and Faber, 1999.

Emerson, Ralph Waldo. Letters and Social Aims. Boston and New York: Houghton Mifflin, 1904.

- - -. The Collected Works of Ralph Waldo Emerson. Vol. II. Cambridge, Mass. and London: The Belknap Press of Harvard UP, 1979.

- - - The Collected Works of Ralph Waldo Emerson. Vol. III. Cambridge, Mass. and London: The Belknap Press of Harvard UP, 1983.

English, James. The Economy of Prestige: Prizes, Awards, and the Circulation of Cultural Value. Cambridge: Harvard UP, 2005.

Finch, Annie, and Varnes, Kathrine, eds. An Exaltation of Forms. Ann Arbor: University of Michigan Press, 2002.

Fletcher, Angus. A New Theory for American Poetry. Cambridge, Mass. and London:

Harvard UP, 2004.

Fredman, Stephen. A Concise Companion to Twentieth-Century American Poetry. New York: Blackwell, 2005.

Gery, John. "Ashbery's Menagerie and the Anxiety of Affluence." The Tribe of John: Ashbery and Contemporary Poetry. Ed. Susan Schultz. Tuscaloosa: University of Alabama Press, 1995. 126-145. 
Göske, Daniel. "Hanoi, Buchenwald, Nueva York: (Trans)National Identities in Contemporary American Poetry." Negotiations of America's National Identity. Vol. II. Ed. Roland Hagenbüchle and Josef Raab. Tübingen: Stauffenburg Verlag, 2000. 229-247. Gradschools.com. "English Language and Literature Graduate School Programs." November 2004: http://gradschool.about.com/gi/dynamic/offsite.htm? site=http\%3A\%2F\%2Fwww.gradschools.com\%2Flistings\%2Fmenus\%2Feng_lang_menu.html. Graham, Jorie. Materialism. Hopewell: The Ecco Press, 1993.

- - - The Dream of the Unified Field: Selected Poems 1974-1994. Hopewell: The Ecco Press, 1995.

- - -. The End of Beauty. Hopewell: The Ecco Press, 1998.

Herd, David. John Ashbery and American Poetry. Manchester, Manchester UP, 2000. Hirsch, Edward. How To Read A Poem. San Diego: Harcourt, 1999.

Hoover, Paul, ed. Postmodern American Poetry: A Norton Anthology. New York \& London: W. W. Norton \& Company, 1994.

Jones, Howard Mumford. The Theory of American Literature. Ithaca: Cornell UP, 1948. Kaufman, Alan, ed. The Outlaw Bible of American Poetry. New York: Thunder's Mouth Press, 1999.

Lee, Arthur Robert. Multicultural American Literature. Edinburgh: Edinburgh University Press, 2003.

Lehman, David, ed. Ecstatic Occasions, Expedient Forms. Ann Arbor: The University of Michigan Press, 1996.

- - -. Great American Prose Poems: From Poe to the Present. New York: Scribner, 2003. MacGowan, Christopher. Twentieth-Century American Poetry. New York: Blackwell, 2004.

McGrath, Campbell. “What's American About American Poetry?” Poetry Society of America. 20 November 2004 <http://www.poetrysociety.org/mcgrath.html>. Menand, Louis. "All That Glitters.” The New Yorker Dec.-Jan. 2005/06. 20 March 2006 <http://www.newyorker.com/critics/content/articles/051226crbo_books>. Messerli, Douglas. From the Other Side of the Century: A New American Poetry, 1960-1990. Los Angeles: Sun and Moon Press, 1994.

Pearce, Roy Harvey. The Continuity of American Poetry. Princeton: Princeton UP, 1961. Perloff, Marjorie. "Normalizing John Ashbery." 25 October $2005<$ http:// wings.buffalo.edu/epc/authors/perloff/ashbery.html>. Poetry Society of America. 20 March 2006 <http://www.poetrysociety.org/ mcgrath.html>.

Ramazani, Jahan, et al., eds. The Norton Anthology of Modern and Contemporary Poetry. 2 vols. $3^{\text {rd }}$ ed. New York \& London: W. W. Norton \& Company, 2003.

Rothenberg, Jerome, and Pierre Joris, eds. Poems for the Millennium. 2 vols. Berkeley etc.: University of California Press, 1995.

Schultz, Susan M., ed. The Tribe of John: Ashbery and Contemporary Poetry. Tuscaloosa etc.: University of Alabama Press, 1995.

Shaw, Robert. “Tragic Generations.” Poetry January (2000): 210-19.

Silliman, Ron, ed. In the American Tree. Orono, Maine: National Poetry Foundation, 1986.

Spiegelman, Willard. “The Nineties Revisited.” Contemporary Literature 42:2 (2001): 206-237.

Van Doren, Carl. What is American Literature? New York: W. Morrow \& Co., 1935. 
Vendler, Helen. The Breaking of Style: Hopkins, Heaney, Graham. Cambridge, MA: Harvard UP, 1995.

Waggoner, Hyatt H. American Poets: From the Puritans to the Present. Boston: Mifflin, 1968.

Whitman, Walt. Leaves of Grass. Ed. Harold W. Blodgett and Sculley Bradley. New York: W. W. Norton \& Company, 1965.

poetry; American; contemporary; originality; influence

Ruediger Heinze, Albert-Ludwigs-Universität, Freiburg, Germany

\section{NOTES}

1. The title is taken from a poem and a collection of poetry by Jorie Graham of the same name.

2. The making of anthologies as a process of canonization rightly begs questions of quantitative and qualitative representation, of ideology, censorship and processes of exclusion. While these aspects are given ample attention in current discussions on canonization and anthologizing, irrational and random aspects of selection, admittedly difficult to analyze, are mostly ignored. For example, mood and topical personal disposition of the editors, questions of taste regarding layout and cover letter or chance aspects of lost manuscripts etc. always influence selection to a degree which is difficult to assess, let alone quantify.

3. All of these are problematic and freighted terms, just as the "innovative" and "genuine" to follow.

4. It would of course be unreasonable to suggest that this is the main and only tenet of Shaw's argument. In fact, these comments mark only the conclusion of his essay on the fin de siècle poetry of the not-quite-so "tragic generation" of poets following the confessional poets of the fifties and sixties. As a conclusive remark, however, the comments are anything but marginal.

5. For a partial critique of this romantic myth of the writer vs. the reality of the marketplace see The Economy of Prestige by James English (2005) and The World Republic of Letters by Pascale Casanova (2005), or Louis Menand's review of them in the Dec. 26, 05/Jan. 2, 06 issue of The New Yorker.

6. Christopher Beach in his book Poetic Culture is one of the few to comment extensively and not derogatorily on the poetry academy system.

7. Here, too, the internet plays an important role. Web radio and audio files of poems facilitate the distribution of poetry as read.

8. A more subtle reading within that rhetoric is John Gery's essay in the same volume. Incidentally, Ashbery's poetry is also the center of a "breakthrough narrative" debate that structurally resembles the opposition between coherence and forfeiture. For a summary of the key points, see Marjorie Perloff's essay "Normalizing Ashbery." 9. More precisely, Derrida claims that iterability governs language, although logically the exact context (time and location) of the speech act cannot be repeated, nor its illocutionary aspect. Quotation is thus not a proof - contrary to what Derrida claims 
and in accordance with Searle - of language's iterability but rather of its differences, while paradoxically iterability implies difference. Nevertheless, Searle reciprocally conflates text and speech act intention. Important for this discussion is the notion that while a text may be iterable through citation, its intention and original illocutionary context are not, so that citation or "re-reading" necessarily means "misreading." It should be kept in mind that the meaning of "misreading" in the context of this debate is restricted to language philosophy and does not connote voluntary distortion. 10. Though not always; see, for example, Foucault's book-length study of Roussel, or any number of essays by Barthes, e.g. on Queneau and Sollers.

11. According to the criticism of commodity poetry, the distinction between "good/ original" poetry and "mass-produced workshop" poetry is, ironically, often tantamount to the distinction between high and pop culture, although classroom/workshop poetry of course almost always has as its aim "high art" as opposed to "popular" poetry, for example Hallmark Card verse, rock lyrics or rap rhymes.

12. In their anthology An Exaltation of Forms Finch and Varnes have collected a substantial number of poetic forms used or invented by contemporary American poets, among them Anthony Hecht, Maxine Kumin, Marilyn Hacker, Pat Mora and Lewis Turco.

13. This attack is also revealing because it is frequently used without further reflection as a corollary to the "Hallmark" attack mentioned earlier: both taken together constitutes a logical fallacy.

14. These remarks refer to her volume Materialism and her selected poetry The Dream of the Unified Field, which won the 1996 Pulitzer Prize.

\section{ABSTRACTS}

This paper collates two critical ideas about American poetry: originality and influence. Under the precept of the former, poets and critics call for - and on occasion celebrate - an originally American, more or less coherent national poetry, while the latter hosts complaints about the "forfeiture of grand opportunities" (Shaw) exactly because contemporary American poetry fails to contribute to a genuinely innovative national literature. This failure is argued to be the result of an inability of poets to free themselves from incapacitating literary influences due to the "academization" and "inbred professionalism" (Altieri) of the creative writing programs. Both ideas, this essay will argue, although apparently oppositional, are based on the same - inherently inconsistent - notion of influence and predominantly appear in the context of discussions around the project/idea of a national poetry/literature. The paper will examine the critical history of these two ideas and their connection to the conception of an American national poetry.

\section{INDEX}

Keywords: Poetry, American, contemporary, originality, influence 
AUTHOR

RUEDIGER HEINZE

Ruediger Heinze, Albert-Ludwigs-Universität, Freiburg, Germany 